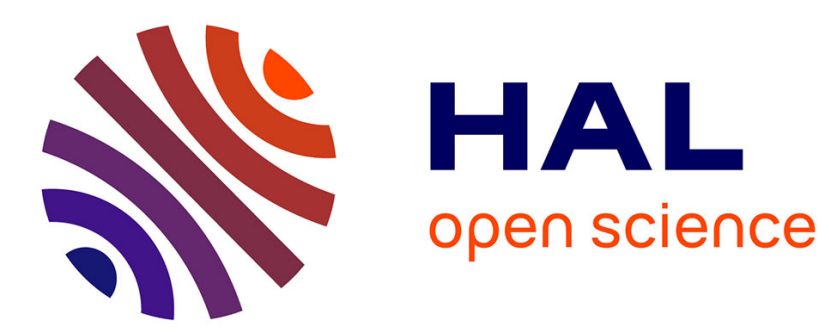

\title{
Declining Evenki 'Identities': Playing with loyalty in modern and contemporary China
}

Aurore Dumont

\section{To cite this version:}

Aurore Dumont. Declining Evenki 'Identities': Playing with loyalty in modern and contemporary China. History and Anthropology, 2017, Loyalty and Disloyalty on the Russia-China border, 28 (4), pp.515-530. 10.1080/02757206.2017.1351363 . halshs-02520204

\section{HAL Id: halshs-02520204 https://shs.hal.science/halshs-02520204}

Submitted on 26 Mar 2020

HAL is a multi-disciplinary open access archive for the deposit and dissemination of scientific research documents, whether they are published or not. The documents may come from teaching and research institutions in France or abroad, or from public or private research centers.
L'archive ouverte pluridisciplinaire HAL, est destinée au dépôt et à la diffusion de documents scientifiques de niveau recherche, publiés ou non, émanant des établissements d'enseignement et de recherche français ou étrangers, des laboratoires publics ou privés. 


\section{Declining Evenki 'Identities': Playing with loyalty in modern and contemporary China}

\section{Aurore Dumont}

To cite this article: Aurore Dumont (2017) Declining Evenki 'Identities': Playing with loyalty in modern and contemporary China, History and Anthropology, 28:4, 515-530, DOI: 10.1080/02757206.2017.1351363

To link to this article: http://dx.doi.org/10.1080/02757206.2017.1351363

曲 Published online: 02 Aug 2017.

Submit your article to this journal $\widetilde{ }$

View related articles 주

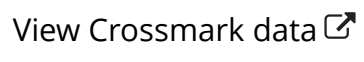




\title{
Declining Evenki 'Identities': Playing with loyalty in modern and contemporary China
}

\author{
Aurore Dumont
}

\begin{abstract}
Officially recognized as a single 'ethnic minority' in the Chinese administrative system, Evenki groups belong to a distinctive geographical and cultural milieu. This case study analyses Evenki expressions of loyalty to state authorities and relation to changing identities in modern and contemporary China. What kinds of 'loyalties' did Evenki proffer to their rulers and/or neighbours? How did these flexible loyalties evolve, strengthen, or disappear over the decades? The first section explores how the Evenki's multiple identities have been shaped over the last two centuries and how their loyalty shifted from one state authority to another and to one or several groups of people. In the second section, the constructed category of Evenki, intertwined with the evolving 'identity' formation, will be analysed through the prism of the everyday contemporary practices and discourses witnessed during ethnographic fieldwork conducted between 2008 and 2016.
\end{abstract}

\section{KEYWORDS}

China; Evenki; 'Identity'; loyalty; ethnonyms; everyday practices

In the People's Republic of China, the puzzle of the 55 'ethnic minorities' (shaoshu minzu 少 數民族 $)^{1}$ is the result of a complex political process undertaken after the establishment of the People's Republic of China in 1949. A single 'ethnic minority' often encompasses diverse subgroups which do not necessarily recognize themselves as being part of the minority in question. This applies to the 'Evenki ethnic minority' (Ewenke shaoshu minzu 鄂溫克少數民族), whose 30,875 members $^{2}$ live in the Northeastern part of Inner Mongolia and Heilongjiang provinces. The 'Evenki ethnic minority' is composed of the Solon, the Khamnigan and the Reindeer Evenki. The relatively small size of these Tungusic language-group populations does not mean that they are homogenous in terms of either their historical background or their economic, religious and cultural practices.

Under the Qing Empire (1644-1911), the vast Sino-Russian-Mongolian frontier was made up of isolated regions that were administered separately from the Chinese provinces. The formation of 'frontier societies' was linked to the condition of permeable borders, subject continually to migrations and political adjustments. The Evenki subgroups ${ }^{3}$ experienced the governance of the frontier differently: while some gave their loyalty to Manchu rulers, others were Russian subjects who crossed the frontier guarded by their 'ethnic relatives'. The most numerous Evenki subgroup today, the Solon, were organized into the tribute and regional defence (banner) system of the Qing Empire. In 
the eighteenth century, some Solon were dispatched to the Hulunbuir steppe (around Buir Lake: see Map 1, Introduction), where they served as garrison soldiers and became a pastoral people. Meanwhile, organized into separate banners in the Heilongjiang taiga-forest zone in Northeastern Manchuria, other Solon groups gradually abandoned their hunting practices to engage in farming following contact with Chinese neighbours in the twentieth century. In contrast to the Solon, who were long-term subjects of the Qing, the less numerous Khamnigan and Reindeer Evenki are 'newcomers' from Russia who fled over the borders of contemporary China at the end of the nineteenth and the beginning of the twentieth centuries. The former now engage in Mongolian-type pastoralism on the steppe, while the latter are nomadic reindeer herders in the taiga-forest areas. In 1957, the Solon, Khamnigan and Reindeer Evenki were merged into the single official 'ethnic category' of Evenki. Their distinct cultures and histories were, in the eyes of the Chinese state, dissolved into a single political entity. This, in the same move, aimed to eradicate any trace of their former loyalties to other imperial powers.

However, the dominance of this homogenization narrative is called into question by fieldwork findings that bring to light multiple expressions of loyalty to state authority present within the various forms of Evenki 'identity'. These can be shaped in discourses about everyday life and practices, during festive events and religious ceremonies, or through the act of remembering and narrating their Manchu or Russian pasts. This case study analyses Evenki expressions of loyalty in terms of the shifting 'identities' characteristic of modern and contemporary China. The loyalty issue is an appropriate key concept for investigating interchangeable categories of 'identity' as perceived by both the Evenki and outsiders across the decades. By 'identity', I refer to the interchangeable political categories conferred by the state authorities on Evenki groups on the one hand and the distinct expressions of belonging used by people to define themselves on the other hand. The concept of loyalty is to be understood as a mutable expression of adherence, subjection, self-interest or action towards a given object of allegiance, such as a recognized superior or a structure, political and otherwise.

The various categorical 'identities' conferred on the Evenki by political centres and neighbouring groups led to the formation of multiple-layered loyalties which Evenki subgroups may have offered to their own group, their rulers and even to their economic partners. What kinds of 'loyalties' did Evenki extend to their 'rulers' and/or neighbouring populations? How did these flexible loyalties evolve, strengthen or disappear over the decades? How were these loyalties distinctively expressed?

In the present case study, notions of 'identity' or 'expression of belonging' are intertwined with the idea of showing loyalty (or disloyalty) to different social actors. While 'identity' and 'loyalty' are highly distinct concepts, they may also intersect. Indeed, the process by which belonging is claimed involves a set of practices demonstrating one's loyalty to a preferred social entity according to given contexts. The various Evenki expressions of belonging may be interpreted not only from the degree of loyalty that local people assign to their own 'Evenki minzu', but also from that which they offer to their Mongol and Chinese neighbours and/or to their respective local governments.

The first section explores how multiple Evenki statuses were shaped over the centuries and how their primary loyalty may have switched from one power to another, and focused on one or spread to several groups of people. In the second section, the constructed category of Evenki will be analysed through the prism of the everyday contemporary practices 
and discourses that were witnessed during ethnographic fieldwork conducted between 2008 and 2016 in the Hulunbuir region and Heilongjiang province. In which context do people move from a single category to heterogeneous ones and vice versa? Why do people choose, under certain circumstances, also to be part of the homogenous Evenki category?

\section{The Solon as loyal Manchu subjects}

Situated on the physical margins of the empire, the territory of the Tungus and Mongol populations ${ }^{4}$ was also the ancestral homeland of the Manchu. ${ }^{5}$ In the wake of repeated Tsarist Russian incursions into the area between the sixteenth and nineteenth centuries, ${ }^{6}$ the Qing rulers formulated specific policies to assert imperial authority over its Northeastern territories and populations. ${ }^{7}$ One of them was the integration of the Solon (Suolun 索 倫) into the Eight Banners System (Baqi 八旗), 'a hybrid institution that combined a range of military, social, economic, and political functions' (Elliott 2001, 40). The Manchu found 'ideal' subjects in the Solon: their great knowledge of remote areas and considerable martial skills were valuable attributes for fulfilling military and tribute duties. Based mainly on military service and the receipt of tribute, a close Manchu-Solon relationship was maintained by hierarchical promotion and profitable trade for the Solon and other natives.

The Solon were described as 'People of the borders whose language and customs were different from the inner areas' (Guo [1926] 1988, 164). Meaning 'shooters' or 'archers' (Fang $1948,66)$, the term Solon was not an auto-ethnonym, nor did it refer to a single people. Sharing related Altaic languages as well as nomadism and hunting and archery skills, the Dahur (Daur, Dawo'er 達斡爾), Oroqen (Elunchun 鄂倫春) and Evenki clans were labelled a single Solon people by the Qing. ${ }^{8}$ This political categorization of populations was aimed at facilitating their integration into the Manchu sphere of influence.

In 1684, groups of Solon and Dahur were incorporated into Butha banners in the Heilongjiang province, where their main duties consisted of providing tribute and serving in the military service. In order to gain their subjects' loyalty, the Qing relied on existing ethnic solidarities, organizing the Solon into units led by their tribal and clan chiefs. The Butha soldiers participated in the major military campaigns that expanded the Qing Empire. One of the most emblematic figures of faithful adherence to the Manchu throne was the Butha Solon general Hailancha 海蘭察 (1740-1793), who commanded troops as far away as Xinjiang ${ }^{9}$ and Tibet in the eighteenth century. Hailancha gained the reputation of being one of the most prominent military officers of the Qianlong reign (1735-1796) and was portrayed four times in the 'Cabinet of purple glory' ${ }^{10}$ for his victorious military service (Zhao 2014, 37).

The Manchu management of the Tungus territories also led to the fragmentation of Solon societies. In 1732, in order to restrain Russian territorial expansion on the SinoMongolian border, the Manchus completed their frontier establishment with the creation of the Hulunbuir banner garrisons. Together with other groups (Old Barga, Dahur and Olot), Butha Solon bannermen were transferred to the Western steppe region of Hulunbuir, where they became pastoralists. Close to the border, troops were stationed at sentry posts manned by rotas of herders, where they prevented crossings in and out of Qing territory and livestock theft (Kim 2009, 138). Each group was given a defined territory 
for its livestock and was made responsible for guarding this territory against intruders. By guarding the borders against external influence, the Solon had to confirm their loyalty to the Manchu rulers instead of to akin Tungusic groups living on the other side of the border.

One technique whereby the Qing rulers maintained the loyalty of their Northern frontier subjects was by bestowing titles and promotions. For their exemplary performance in keeping the Qing frontiers safe, some Solon were promoted to the intermediate and higher ranks of the regional military hierarchy. For quelling the 1864-1882 Muslim rebellion in Xinjiang, the Qing made the Solon and Sibe part of the 'New Manchu' category (Kim $2009,62) .{ }^{11}$ Those without military duties, like the Solon superintendent administering the Butha banners, were clan or village chiefs who served without pay. However, their prestige was enhanced by the imperial titles they received (Lee 1970, 51).

Like Siberia, Manchuria was rich in valuable resources such as tigers, bears, sable and deer (Meng [1931-1934] 1968, 3). This not only provided for the Tungus' subsistence system (food and clothing), but also for the Qing's most profitable acquisition, the tribute. The systematization of tribute collection began in 1689 (Lee 1970,48). Officers called anda were responsible for collecting an annual tribute of sables from peoples not yet incorporated into the empire, who would gather at appointed places to meet the officers (Lee 1970, 51). Common to both the Manchu and Tungusic languages, the word anda (sometimes spelled andak depending on linguistic variations) means 'friend' or 'comrade'. ${ }^{12}$ During the tributary presentation, the pelts were graded according to quality; those that were not chosen as tribute were released for private trading (Lee $1970,49)$. The imperial centre gained valuable natural resources and in return distributed essential goods that were not produced in the region. This arrangement created economic relations between the state and its subject tributaries (Kim 2009, 6). The tribute was not only a strategy of control and political submission: as rewards for their meritorious services, either military or economic, the Solon were given opportunities for profitable trade, which was important for nomads. The Solon were not only highly valued as garrison soldiers: during the Manchu period, the Solon of Butha attended archery competitions organized in Qiqihar by the military office, and those who displayed considerable skill were given higher ranks in the hierarchy (Lü 1983, 25). Thus, the Tungus populations played a decisive role in Qing history and were essential components of the Manchu strategy for the defence of the Northern borders. A triangular relationship based on control, promotion and economic networks maintained loyalty between the Solon and their rulers. Still, the frequent movements of other Tungusic groups also showed that border guarding was selective: some of the people whom the Solon were supposed to prevent from crossing settled in China in waves-which may, or may not, suggest a certain covert disloyalty too.

\section{The Reindeer and Khamnigan newcomers: the Russian subjects}

Defeated by the Cossack invaders, the Reindeer Evenki scattered in Southeast Siberia had been forced to pay taxes (yasak) from 1623 to Tsarist Russia (Lindgren 1938, 608-609). In order to avoid this and find better hunting grounds, a few groups crossed the border between the early-eighteenth and mid-nineteenth centuries to settle in the Three Rivers region (Sanhe 三河, Russian Trekhrech'e, see Map 1, Introduction) ${ }^{13}$ on the Qing side. Lindgren $(1930,525)$ reported how the Manchus were disturbed by the rumour that a 
small group on their territory was trading with the Russians and considered itself subject to their government. In 1915, after the fall of the Qing dynasty, Shirokogoroff ([1929] 1979, 67-68) witnessed: 'their administrative centre was on the banks of the Amur [the border], where they paid certain tribute, while they went to another village called Prokovka [Fukeluofuke 甫克落夫克] to marry in the Orthodox Church, baptize their children, keep records and trade'. While being Russian subjects on the Chinese side, the Tungus also maintained close economic ties with another group of refugees: the Cossack farmers settled in the villages ${ }^{14}$ of the region.

After the Russian Revolution, the Cossacks began paying a tax to the Chinese yamen [local administration] for the right of carrying on the Reindeer Tungus trade [...] while Chinese officials in the border settlements did not succeed in asserting any authority over the Reindeer Tungus. (Lindgren 1936, 83, 85)

This trade was based on a relationship between the Evenki and Russian, again called andak. While a Russian could have multiple Evenki andak, an Evenki could have only one Russian partner (Lindgren 1938, 616). The Evenki traded furs and skins (red squirrel, lynx and sable) in exchange for food products, ammunition and gunpowder. Called bogžor in Evenki, the meetings between the two parties took place four or five times a year (Kajgorodov 1968, 125). When a bogžor was held in a Russian village, Tungus families were housed with their respective andak families (Lindgren 1938, 611-612). Lindgren also reported on the exchanges of techniques and materials between the two communities: the Evenki used scissors, knives and forks, dishes, thimbles and needles and baked bread, while the Russians dressed their children in Evenki boots. The Reindeer Evenki maintained close economic relationships with their Cossack partners until the 1950s, who then fled, or were forced, back to the Soviet Union.

Another group of Tungus newcomers, the Khamnigan, first left Russia to settle in the Western areas of Hulunbuir after the October Revolution, but the waves of migration continued until 1934 (Janhunen 1996, 52). ${ }^{15}$ Before being dominated by the Cossacks, to whom they had to pay tribute, the Khamnigan had been dependent on the Halh Mongol princes. Influenced by both the Mongols and the Russians, the Khamnigan combine cultural elements borrowed from each of these sources. Upon their arrival in China, the Khamnigan lost most of their herds, forcing some of them to become pastoral workers for Russians, Buryats and Barga (NZBZ 1986, 310).

Thus, in the first half of the twentieth century, the Solon, the Khamnigan and the Reindeer Evenki were scattered across a large area between the steppe and the taiga along the Sino-Russian-Mongolian border. Each of them came under various spheres of influence, maintaining or establishing ties with different groups (Chinese, Russian and Mongol) according to changing political powers: they also did this on a local scale, according to people's day-to-day needs. Evenki-Cossack trade shows how loyal ties (long-lasting and/or exclusive partnerships, andak) could be formed across the border and between refugees from different backgrounds scattered on the Chinese side of the border.

From the former Solon bannermen enrolled in the Manchu political system to the Reindeer Evenki and Khamnigan 'newcomers' from Russia, who maintained close relationships with other refugees, these various regional Tungus groups scattered along the border experienced a new challenge in the 1950s: they were merged together into a new political categorical identity. 


\section{Struggling with ethnonyms: becoming a single 'Evenki Ethnic Minority' (1957)}

The Tungus' means of demonstrating their loyalty, either as Manchu frontier guards or as economic partners of the Russians, had particular resonance for the Communists when choosing an official ethnonym. In the early 1950s, the 'Ethnic Classification Project' was carried out in order to identify the different groups of the nation. ${ }^{16}$ In the Tungus areas, the task was made difficult by the multiple auto-ethnonyms and exo-ethnonyms used by and for the Evenki. As witnessed by Shirokogoroff in the 1910s, 'Numerous groups know themselves to be Evenki, but between them, they do not use this term, they distinguish social units and use "Evenki" only in reference to themselves as compared with other distinct groups' (Shirokogoroff [1929] 1979, 54). When most of the Tungus people were still nomads, the use of ethnonyms and exo-ethnonyms was a way of conferring loyalty to kinship groups as against enemies, especially when hunting grounds were concerned. Among Reindeer Evenki, the most common self-designation followed the names of the rivers along which they nomadized. For example, the Geilik clan members who lived next to the Jin River called themselves 'People of the Jin'. However, on each side of the frontier, Evenki groups were labelled in various other ways by their neighbours, which resulted in a very confused situation for outsiders. In the forest zones, the Reindeer herders were called Tungus by the Tsarist government and Yakut by the Russians of the Three Rivers region, while they were the Yakut Orogen for the Khamnigan (NZBZ 1986, 148-149). The Solon were known as Solon by the Khamnigan, the Reindeer Evenki and the Mongols, while the Oroqen called them Evenki and the Dahur labelled them Xongor (NZBZ 1986, 13; QRDDMWB 1957, 8). In the steppe area, the Solon were called Khamnigan (Gemunihan 咯穆尼漢) or Tungus (Tonggusi 通古斯) by the Russians (Xi [1810] 1936, juan 3, 30) and Tungus by the Chinese from Liaoning (Meng 1931-1934, 193). Finally, the Khamnigan were known as Tungus by the Chinese, Dahur, Russians and Reindeer Evenki, while the Buryat called them Khamnigan.

The relatively common use of the Evenki ethnonym by some groups was decisive in the adoption of Evenki as an official ethnonym in 1957. After first rejecting the major exo-ethnonyms on the grounds that they were not used by the Evenki themselves, the Chinese government changed their minds and finally decided to designate the Solon, the Khamnigan and the Reindeer Evenki according to the previously renounced exo-ethnonyms: the 'Solon Evenki' (Suolun Ewenke 索倫鄂溫克), the 'Tungus Evenki' (Tonggusi Ewenke 通古斯 鄂溫克) and the 'Reindeer Evenki' (Yakute Ewenke 雅庫特鄂溫克). By selecting Evenki as the official name for the three groups, the Chinese government split the former Solon entity (composed of the Evenki, Dahur and Oroqen) into three distinct 'ethnic minorities', while the Khamnigan and Reindeer Evenki 'newcomers' were merged into the newly created 'Evenki ethnic minority'. By gathering together three groups who did not share the same history or domestic economy, the central government strove to erase all references to their past as imperial subjects of the Qing and Russian Empires and create a new loyalty.

In the socialist period, ethnic policy is a combination of the Qing legacy and socialist affirmative action (...); the Communists built a multi ethnic society in which all groups are equal but must also remain loyal to the Socialist state. (Tang and He 2010, 42-43) 
In this process, the 'Evenki ethnic minority' was given several ethnic administrative villages (one for the Reindeer Evenki, one for the Khamnigan and three in the Solon forest zone) and one Evenki autonomous banner, all of which were geographically distant from each other.

The single entity was created with a set of propaganda tools (movies, tourism) highlighting the homogeneity of the Evenki in the Chinese mass media. After six decades under an assigned 'Evenki ethnic minority' label, how does each subgroup define their differences and how is loyalty expressed in various contexts? In the localities, while people may uphold ties towards their own group, they do not necessarily cut ties with the overarching official category since different kinds of loyalties may be intertwined. Asking people living in the Evenki villages where their loyalty lies would be difficult, since loyalty is a loose and abstract term which can be understood in various ways. Indeed, everyday discourse and practices are valuable clues for distinguishing loyalty without explicitly naming it: in the field, people engage themselves in the explanation of what they consider to be their own group. I argue that claiming to belong to a given group encompasses a set of actions which not only reflect one's membership of a given community, but also assert loyalty to it. I suggest that the promotion of one's self-belonging reflects the flexible 'intersecting loyalties' with which the Evenki are engaged.

\section{Playing with ethnonyms}

At a local level, the official Evenki category actually encompasses a variety of regional encounters. The alternate use of ethnonyms, exo-ethnonyms and Chinese administrative categories as forms of self-designation is the first way to legitimate belonging to a given group. The identification with a given local group is not only a matter of self-representation, since it also highlights the manner in which people assert loyalty to their own regional group.

The Evenki do not know much about each other: the available sources of information are mainly the media and hearsay, as I found out during my field research. When asking questions about another group, people answered only, 'this group is not like us'. Separated by hundreds of kilometres, the different groups usually do not meet except for specific occasions like official celebrations. Isolated from one another, each regional group prefers to establish ties with neighbouring populations. The Reindeer Evenki, the Solon and the Khamnigan distinguish themselves first through the geographical milieu in which they live. The steppe and the taiga, which support certain herding practices, are conceived of as two opposite environments. When they are in their own locality and talk about other groups, Evenki refer first to 'environmental categories'. For the Reindeer herders, who call themselves Evenki, an Evenki people is supposed to possess reindeer and valuable knowledge of reindeer herding and hunting. The Reindeer Evenki call the other groups 'Evenki of the steppe' (Caoyuan Ewenke 草原鄂溫克). In the same manner, the Solon and the Khamnigan, who engage in Mongolian-type 'five muzzles' pastoralism, ${ }^{17}$ refer to the Reindeer Evenki as 'Evenki of the Forest' (Senlin Ewenke 森林鄂溫克).

By contrast, Chinese administrative categories are mostly used when introducing oneself to someone who is unfamiliar with the area or when people meet outside their regions of residence. When meeting people, Evenki first use the official ethnonym Evenki, which is then followed by either the ethnonym of their official subgroup (Reindeer 
Evenki, Tungus, Solon) or the name of their administrative district. The Reindeer Evenki call themselves 'Evenki of Aoluguya' (Aoluguya Ewenke 敖魯古鴉鄂溫克), which is also the name of their ethnic village, or 'Evenki of Genhe', which refers to the biggest city near their village. The Solon of the Steppe call themselves 'Evenki of Huihe' or 'people from the Evenki Autonomous Banner', since they are the only Evenki living in this banner. The Khamnigan introduce themselves as the 'Evenki people' (Evenki boye): however, if one asks to which group they belong, they either say 'Khamnigan'18 (the appellation given by the Buryats), 'Tungus' (the Chinese administrative appellation) or 'Evenki of the Old Barga Banner'. The use of Chinese official categories (both ethnonyms and administrative places) by the Evenki is a well-established practice, one which reveals that, even though the Evenki use official nomenclature as a tool of designation for themselves and other groups, they do not necessarily recognize it as an ethnic category. Conceptions of self-representation and belonging may shift from the official category to the regional group's self-understanding. Alongside discourse and appellations, a large set of practices in everyday life highlight the intersected loyalties of the Evenki: these loyalties can be bestowed upon their own group, their neighbours and the local authorities.

\section{Being loyal to one's group, sharing loyalties with neighbouring populations}

Which traits claimed by each group to be 'Evenki' reveal a bond of loyalty to the group?

These 'Evenki marks' may be attitudes towards clothes and food, herding techniques, or their Russian past.

Although the 'traditional herding' of the Reindeer Evenki has been somewhat artificially promoted for the sake of tourism by the local authorities, it remains a strong marker for the community. Herding requires a large range of skills, but the most valued is one's capacity to manage a nomadic camp (looking after the reindeer, maintaining a nomadic camp without experiencing physical difficulties) and knowledge of grazing patterns, the detailed techniques of reindeer herding, and hunting for fur. Other skills, such as sewing fur clothes or making birch-bark objects, appear to be 'proofs' of belonging to the Reindeer Evenki community. Thus, keeping up reindeer-herding practices in the face of modern alternatives is the first criterion for Reindeer Evenki in demarcating themselves from the other Evenki groups, and thus demonstrating their loyalty towards their small community of 250 people. They always say: 'Without reindeer, Evenki would not exist anymore'.

This multi-ethnic area also allows Evenki groups to maintain 'shared loyalties' with neighbouring populations. Indeed, loyalty may also be a consequence of long-term relationships governed by trust and reciprocity. Those interactions include regular cooperation in herding and social practices (marriages, festivals). In the Reindeer Evenki area, the reindeer has been a state protected animal since 2008, while hunting has been banned since 2003. However, reindeer herding and hunting are parts of an informal economic system involving the Evenki and Chinese partners. Building ties of loyalty based on reciprocity and discretion is necessary for both sides to maintain this informal economy.

In the steppe area, the Khamnigan and the Solon live alongside the Mongols, with whom they share pastoral practices and the Mongolian language. How do the Evenki demarcate themselves from their Mongol and Buryat neighbours? In Hulunbuir, two 
Khamnigan communities can be distinguished: the most numerous live in the Evenki ethnic village of the Old Barga Banner, while the second group, which arrived during the last century with the Buryats, has been installed alongside the latter in the Evenki autonomous banner. Khamnigan traditional clothes, made with colourful fabric and sheep wool, are famous in the community and are worn on special occasions, such as marriages, festivals and other celebrations. The Khamnigan claim that the Buryat borrowed their clothes, while the Buryat claim the opposite (Lü Guangtian, who conducted fieldwork in Evenki areas in the 1950s, reported on this issue). However, while the Khamnigan consider the Buryat to be a Mongol people in order to differentiate themselves from them, they feel much closer to the Buryat than to the Solon and Reindeer Evenki. The Khamnigan have close relationships with their Mongolian neighbours, with whom they marry, work and share economic ties, especially in terms of herding practices. ${ }^{19}$

Loyalty can also come from shared religious beliefs. In the steppe area, the Evenki possess their own oboo, which are sacred monuments marking out the notional centres of social groups. 'Since the eighteenth century, virtually every male-based social group -banners and sum [village], clans (if they existed), colleges (Aimag) of lamas-has had its own oboo, which is a sign of its connection to the land' (Atwood 2004, 414). The oboo are worshipped annually to prevent calamities, bring good fortune to the community and guarantee the fertility of the herd. The oboo is usually followed by three 'manly games', naadam, archery, horse racing and wrestling, which aim socially and symbolically to reproduce society and its environment. Such customs and shared beliefs may also orient ties of loyalty.

'Disloyal behaviour' to the official Chinese-constructed Evenki entity arises when people reminisce about their Russian or Qing past. In everyday conversation, the Reindeer Evenki and the Khamnigan groups frequently point out that their ancestral home was in Russia and that they are 'newcomers' to China. Both groups consider the Russian people as neighbours, both geographically and culturally (the two villages are not far from the Russian border). Even though most people no longer remember their former lives in Russia, many know oral stories from their elders, relating how Reindeer Evenki used to cross the Russo-Chinese frontier. While remembering his Russian partners in the Three Rivers region, an elder named Grishka told me that more than 200 Evenki crossed the border into China in 1922. Some of the elders still know the Russian language they learned in Russian schools in the Three Rivers region. The discourse surrounding this 'remembered past' is often complemented by practices, which are used as proofs of their former Russian belonging. The first is the use of Russian words in naming people and traditional components of Evenki culture. Today, in addition to Chinese and, more seldom, Evenki names, Russian names are given to newborns. In nomadic camps, the cone-shaped dwelling is called a palatka ${ }^{20}$ ('tent' in Russian). This kind of dwelling, which is not used as a living space any more, is perceived by Evenki to be 'traditional'. The modern rectangular tent is called by its Chinese name zhangpeng 帳篷. The vocabulary borrowed from Russian reveals the different products introduced by the Russians into the Evenki community at the beginning of the twentieth century. These terms are mostly deployed in nomadic camps, where the use of the Evenki language is more widespread. Furthermore, while the Evenki language is less and less spoken, everyone, even the young, knows some Russian words. Among many terms noted during my fieldwork, ${ }^{21}$ the following are commonly used: 
Hlieb/lieba [bread]; kapušta [cabbage]; kurica [chicken]; jablok [apple]; aladi [doughnut]; vareni [jam]; čaj [tea]; pivo [beer]; astakan [glass]; pieč [oven]; okoška [window]; nakrivat [bed]; lampa [lamp]; palatka [tent]; mašina [car]; iškole [school]; učitel [teacher]; pulie [bullet]; granica [frontier]; sigaretka [cigarette]. ${ }^{22}$

Furthermore, the Evenki use the Russian term ispasibo to thank people, since their own language does not have an equivalent for 'thank you'. The Reindeer Evenki have kept some recipes from the Russians, including aladi [fried doughnuts]. However, their greatest pride is their Russian-style bread, called hlieb or lieba. The Chinese term lieba 列巴 is the phonetical transcription of the Russian word hlieb [bread]. ${ }^{23}$ This round, crisply baked bread is prepared by the women of the family. The Evenki have added their own cosmological conception to the consumption of the bread: while eating, its curved upper surface represents the sky and should always face upwards. The lower surface, which evokes the earth, must always face downwards. When eating a lieba, one's thumb should hold the sky, and the other four fingers the earth. If one does not follow this rule, it is thought that hunting will not be successful. This bread is also an 'ethnic marker' of Reindeer Evenki. Many groups in Hulunbuir claim to have the original recipe of Russian bread: ${ }^{24}$ so do the Khamnigan and the Buryats. Khamnigan bread is characterized by its rectangular shape and crispy crust, which is a gauge of its quality. In a Khamnigan village, the lieba (also called klemen) is well known and is supposed to represent their Russian past: as they frequently say, 'Our ancestors all come from Russia'. The commonalities shared by the two communities who were former Russian subjects highlight how Russian practices have become part of their Evenki identity.

On the other side of the steppe, while the Solon do not have any Russian or foreign origin markers, they often recall their pasts as former Qing bannermen. Built by generation after generation of Solon clansmen, oboo are believed to have existed for years or even centuries. Each oboo is linked to its founder, who eventually became an ancestor after death. Many who consider themselves the descendants of Qing subjects trace their clan's history back to the mid-eighteenth century, when former bannermen migrated to Hulunbuir. Numerous oral stories recall how, after having settled in a new location, a clan member would build an oboo to mark its territory as against that of other clans. For example, the Bayan Onggor Oboo is believed to have been erected during the Qing dynasty on pasture land used for the first time by the Dular lineage of the Solon Yellow Plain banner (NZEY and HEY 2007, 71).

Furthermore, the Solon possess a specific dwelling called an ege, which is considered a typical Solon dwelling. The first time I met a Solon family in the steppe area of the Evenki autonomous banner, I was brought into an ege. When asking them what it meant for them to be Evenki of the Steppe, the family immediately explained the importance of the ege as a Solon marker, adding that no other Evenki group possesses such a dwelling. While similar to the Mongolian yurt (mongol ger), the Solon ege is larger and distinguishable by its sandy colour and an external cover made of thin willow branches and reed broom. The ege is never isolated and often appears in tandem with the yurt. The spatial arrangement of this duo expresses the importance given by the Solon to their ege: it is always situated on the West side, a place usually occupied by the family elder. The ege is not only a habitat: it is used for weddings, special guests and various kinds of celebrations. Local authorities also like to display the ege for local summer celebrations, such as naadam. 
Whether they use ethnonyms, distinctive dwellings, Russian words or recall their bannermen ancestors, each group tends to value a sense of loyalty primarily towards its own group before others and thus evidence a certain disloyalty towards the official entity.

\section{Ambiguous loyalty with local authorities}

The Evenki have also developed ambiguous loyalty to their respective local governments. While personal loyalty with members of other groups via partnerships and marriage is a medium of social exchange based on equal reciprocity, ties of loyalty established with local authorities are more subject to fluctuation, since local governments are engaged in both the management of Evenki pastoral economy and the manipulation of their local identities. State intervention in herding began soon after the establishment of the PRC. Communist policies led to the transformation of the traditional domestic economy into a more systematic use of fixed dwellings, the reduction of nomadic areas and the creation of socio-professional categories for herders. Initiated at the beginning of 2000, the 'Open Up the West policy' (xibu dakaifa 西部大開發) has promoted the economic development and environmental protection of the Western provinces of China. This modernization project marked an important transition for nomadic peoples. The inclusion of herders in extensive social settings and the position they are assigned in state structures are visible in the organization of today's pastoral economy, touristic development and in the new practices associated with them. The Evenki are connected to local authorities through the different policies applied according to local needs and specificities. In each place, the local authorities are not only responsible for herding management and touristic development: but they are also involved in resolving conflicts and promoting the 'Evenki ethnic minority' in the public sphere. In Aoluguya, local authorities play a central role in herders' everyday lives, since they control reindeer property rights. Today, reindeer herders' sources of income are mainly herding and tourism. For decades, all reindeer antlers had to be sold to the local authorities for a fixed annual price; however, since the 2008 promotion of tourism and the subsequent increase in the number of tourists, the local authorities have adopted a more flexible position to herd management and individual businesses. Since 2012, although the reindeer remains an animal protected by the state, the antlers are not state property any more: the herders are free to sell them either to the local authorities or to other partners. The authorities also provide material gratis at the nomadic camps, such as tents.

In the Khamnigan and Solon areas, the local authorities handle the distribution of pasture to each family. However, many problems with pasture distribution have arisen in recent years, with the local authorities being accused of selling land to private companies. Since local government cannot be avoided, the Evenki have to deal with policies promoted by these authorities. The ambiguous loyalty that the Evenki extend to the local authorities is shaped by material and financial support on the one hand and problems linked to environmental degradation which directly affect the Evenki population on the other hand. After the 'ecological migration' of 2003, the local authorities were accused of being responsible for the deaths of many reindeer after they decided to stable them next to a city. In Khamnigan areas, the extraction of coal has led the authorities to plan to resettle the herders, a matter which has not yet been resolved. 
Furthermore, in Reindeer Evenki and Khamnigan villages, the leaders of the local authorities are Solon from the taiga, the only group without previous ties to Russians. As the most numerous Evenki subgroup, the Solon language and culture should have been designated as officially 'representative' of the overall group. However, little attention has been paid to their regional differences: the Solon of the Taiga are Sinicized farmers, while the Solon of the Steppe are highly Mongolized. The Solon, especially those living in the Taiga, have an ambiguous status: while being noted former Manchu subjects (hence loyal to a previous regime), they appear to be the only subgroup without 'ethnic markers' from the perspective of Chinese propaganda. Paradoxically, they possess heroes who served China in the past and are exhibited in local museums (like General Hailancha). Today, they are to be found in all important bureaucratic spheres (local government, scholars) and research organizations. Should we assume that their former position as Manchu subjects has been rewarded by contemporary China?

On the other hand, given their exclusion from higher administration, the two small Reindeer Evenki and Khamnigan groups have become the representatives of the 'Evenki minority' one encounters in performances, tourism advertisements and museums. Incidentally, these 'newcomers' to China, along with their Russian origins, have become the most frequently referenced Evenki people in the Chinese media and in the promotion of tourism.

Yet, while the Evenki minority may be divided into multiple local entities by authorities according to each group's specificities, this is not always the case. An attempt to create a unified Evenki 'identity' through a festival was made in the early 1990s. In 1993, the Auspicious Festival (Sebin jie 瑟賓節) was officially established to celebrate the 'Evenki ethnic minority'. The content of the festival was formulated by the official Evenki Research Association of Inner Mongolia (Neimenggu Ewenke zu yanjiuhui 內蒙古鄂溫克族研究會), an organization founded in 1984 and composed of Solon intellectuals. The association is a local bureaucratic institution for the cultural enhancement of minority groups and the promotion of the Evenki. So how did it go about trying to create a single entity through which loyalty to the state might be transmitted?

Based on data gathered from the ethnographic literature, the association picked a collective clan ritual formerly organized by the Evenki: this festive event gathered elders, youth, women, men and children to celebrate a new season, a marriage or bear hunting. However, since each community is geographically remote from the others, they celebrated these festivals separately (QZWXW 2008, 951). In order to legitimize the supposedly common origin of these gatherings, researchers pointed out that, a long time ago, all the Evenki lived in the forest as hunters. The common point of origin of this festival required a suitable name and date. The researchers focused on the festive aspect of these rituals, so the Tungus term sebžen, which means 'fun' or 'happiness', was adopted as part of the official name and phonetically adapted to Chinese as Sebin (瑟賓). The official date of 18 June was chosen, since it coincides with two major events. Firstly, June is the beginning of the summer and thus is the time for oboo rituals and naadam games among the local populations. Secondly, June is also connected with the commemoration of June 1957, when the 'Evenki ethnic minority' was officially created. The 'Auspicious/Joyous Festival' is a public event with multiple functions: it commemorates and perpetuates Evenki culture through the reactivation of former traditions and it brings the Evenki together, 
regardless of their geographic location. The first 'Auspicious Festival' was held in 1994 in the Evenki Autonomous Banner. It included songs, choreographed dances with ethnic costumes and naadam games.

However, the standardization of a single 'Auspicious Festival' was a thorny issue, since the different Evenki groups possessed their own celebrations. Over the years, local authorities developed a variety of Evenki 'cultural practices' for each group: the Solon of the steppe and the Khamnigan participate in horse races during their naadam; the Solon of the Taiga engage in 'cattle day'; and the Reindeer Evenki compete in reindeer beauty contests in their ethnic village. There is an official Auspicious Festival held in Hailar, but this is not exclusively an Evenki affair, since anyone can participate. The local authorities are the major organizers of the events on 18 June. Thus, if the 'single label' is valid in mass media, it is no longer so on a local level, since the authorities are engaged in the support of their own group's cultural practices. Despite the unification-on-paper of the three groups, the singular Evenki entity remains an artificial creation, not only for the local peoples but also for local authorities, who have to adjust to local realities and thus are disloyal to the official classification.

Small nomadic groups have always maintained relationships with various external groups, whether they are administrative powers or individuals, and thus ties of loyalty evolved according to changing relationships. Expressions of loyalty underwent several steps in shaping regional belonging in this multi-ethnic frontier region. Under the Qing Empire, military service in the Eight Banners and tributes were among the major policies developed by the Qing to reinforce their imperial authority and gain the Solon's loyalty. The Solon and other native groups had a vital place in the Qing governance scheme of this particular part of the empire's frontier and a respected place in the military. When seemingly similar newcomers settled in China, the communists created a single Evenki category, which led to various processes of recognition by the Evenki and the authorities. Through investigating notions of regional belonging and identification among the different Evenki groups, this paper has attempted to show how local people on the ground experience and deploy multiple attachments. While, in the Evenki case, primary loyalty is mainly understood in local ethnic terms, nevertheless the complexity of belonging to different 'cultural' worlds has been grasped both by Evenki and the local authorities. This makes it possible for loyalty to be devoted not only to the subgroup, but also to neighbours and local authorities.

\section{Notes}

1. The People's Republic of China is officially composed of 56 'nationalities' (minzu): the Chinese nationality of the majority and 55 other groups recognized as minority groups.

2. According to the 2010 Chinese national census.

3. For practical purposes and to avoid any confusion, I use the official contemporary terminology Evenki to refer to the three subgroups (Solon, Reindeer Evenki and Khamnigan Evenki). When one specific subgroup is concerned, I will mention its appellation.

4. Namely, the Oroqen (Elunchun 鄂倫春), the Hezhe (赫哲) and the Evenki, who became three distinct 'ethnic minorities' in the PRC, and different Mongol groups.

5. Here, we refer to Manchuria, broadly speaking as it became defined in retrospect by the Qing rulers.

6. The Russian advances led to the conclusion of a series of treaties (the Treaty of Nerchinsk in 1689, the Aigun Treaty in 1858 and the Peking Treaty in 1860) and the demarcation of the 
Russo-Chinese boundary. Even after the treaties were signed, the Russians attempted to gain more land from the Manchus. For more details related to the establishment of the Amur River (Heilongjiang 黑龍江) as the Sino-Russian Border, see Zatsepine (2007) and Bassin (1999).

7. Although not all native peoples were integrated into the Manchu system, a great number of them were subordinated to Manchu control.

8. Lee $(1970,14)$ has pointed out that in the early Qing records, the Tungus were identified in terms of the localities in which they lived.

9. The descendants of these border guards nowadays form a small community of 72 residents (according to data provided by the Inner Mongolia Evenki museum) in the Yili and Tacheng Kazakh autonomous prefectures in the north of the Uighur autonomous province of Xinjiang. They are part of the 'Evenki ethnic minority', but are most commonly known as Ongkor Solon.

10. The 'Cabinet of Purple Glory' (紫光閣 ziguang ge) was a public military museum under the Qing dynasty which displayed paintings and portraits of meritorious officials.

11. The 'New Manchu' relied primarily on hunting and fishing, rather than agriculture, for their livelihoods (Kim 2009, 61).

12. This term is also known in Neghidal, Manchu, Ulč, Orok, Nanai, Oroč and Udeghe languages. In Mongolian languages (Buryat, Ordos and Dahur), anda first refers first to an ally by marriage and, by extension, to a friend, a military ally.

13. The region's name refers to the Gen 根, Derbul (De'erbu'er 得爾布爾) and Haul (Hawu'er 哈烏 爾) rivers.

14. For example, Aloči (Shiwei 室偉), Ključevaja (Linjiang 臨江) and Karavannaja (Enhe 恩河) are today 'Russian ethnic villages' (Eluosi minzu xiang 俄羅斯民族鄉) where the descendants of former Russian émigrés are settled.

15. Other Khamnigan fled to Mongolia, where some 300 families now live alongside the Buryats (Atwood 2004, 172). Those who stayed in Russia live in the Aga Buryat region. In the three countries where the Khamnigan are established, none formally recognizes them as a separate group.

16. To become a minzu, a group should share a common language, a common territory, a common mode of economic production and a common culture. For a detailed study of the 'Ethnic Classification Project', see Mullaney (2011).

17. These are cows, camels, horses, sheep and goats.

18. In the ethnographic literature, they are also known as the 'Evenki of the Mergel' (Mo'ergele Ewenke ren 莫爾格勒鄂溫克人), which is the name of the river that flows around their ethnic village.

19. Both the Khamnigan and the Solon have economic ties with neighbouring groups: they rent their pastures to the Chinese, but they also hire Barga pastoral workers to cut the grass, which is one of the most important annual activities.

20. The generic Evenki term referring to the tent or the household is dju. However, people would often use the Russian and Chinese terms.

21. A complete list of the Russian terms used in Evenki language can be found in Gu and Sirenbatu (2011).

22. These Russian terms are transcribed according to Evenki pronunciation. The addition of an initial vowel to Russian words is a characteristic of numerous Siberian languages, including Evenki (personal communication from Alexandra Lavrillier).

23. The common Chinese term for bread is mianbao 麵包.

24. Unlike the Khamnigan and Reindeer Evenki districts in the northern part of Hulunbuir, the lieba in the Argun region is a kind of brioche bread made by the Chinese on an industrial scale: it is mainly sold in the Russian shops of Hailar. In Russian ethnic villages situated in Argun region, a type of soft bread is also made.

\section{Disclosure statement}

No potential conflict of interest was reported by the author. 


\section{References}

Atwood, Christopher P. 2004. Encyclopedia of Mongolia and the Mongol Empire. New York: Facts On File.

Bassin, Mark. 1999. Imperial Visions: Nationalist Imagination and Geographical Expansion in the Russian Far East, 1840-1865. Cambridge: Cambridge University Press.

Elliott, Mark C. 2001. The Manchu Way. The Eight Banners and Ethnic Identity in Late Imperial China. Stanford, CA: Stanford University Press.

Fang Dexiu 方德修. 1948. Dongbei difang yange jiqi minzu 東北地方沿革及其民族 [Ethnic Groups and History of Northeastern Areas]. Shanghai: Kaiming shudian.

Gu Xianglian古香蓮 and Sirenbatu 斯仁巴圖, ed. 2011. Aoluguya ewenke yu duben 敖魯古雅鄂溫克 語讀本 [A Reading Manual of Aoluguya Reindeer Language]. Hailar: Neimenggu wenhua chubanshe.

Guo Kexing郭克興. [1926] 1988. Heilongjiang xiangtu lu 黑龍江鄉土錄 [Local Records of Heilongjiang]. Reprint edited by Gao Xiaoyan高曉燕. Harbin: Heilongjiang renmin chubanshe.

Janhunen, Juha. 1996. Manchuria: An Ethnic History. Helsinki: The Finno-Ugrian Society.

Kajgorodov, Anatolij Makarovic. 1968. "Evenki v Trehrec'e. (Po licnym nabljudenijam)." [The Evenki of the Three Rivers Area. (Personal Observations).] Sovetskaja Etnografija 4: 123-131.

Kim, Loretta. 2009. "Marginal Constituencies: Qing Borderland Policies and Vernacular Histories of Five Tribes on the Sino-Russian Frontier." PhD diss., University of Harvard.

Lee, Robert H. G. 1970. The Manchurian Frontier in Ch'ing History. Cambridge, MA: Harvard University Press.

Lindgren, Ethel John. 1930. "North-Western Manchuria and the Reindeer-Tungus." The Geographical Journal 75: 518-536.

Lindgren, Ethel John. 1936. "Notes on the Reindeer Tungus of Manchuria. Their Names, Groups, Administration and Shamans." PhD diss., University of Cambridge.

Lindgren, Ethel John. 1938. "An Example of Culture Contact Without Conflict: Reindeer Tungus and Cossacks of North-Western Manchuria." American Anthropologist 40 (4): 605-621.

Lü Guantian 呂光天. 1983. “Qingdai Buteha dasheng Ewenke ren de baqi jiegou 清代布特哈打牲鄂 溫克人的八旗結構." [The Organization of the Evenki Buteha Banners under the Qing Dynasty.] Minzu yanjiu 3: 23-31.

Meng Dinggong 孟定恭. Jin Yufu 金毓跋. (1931-1934) 1968. Buteha zhilüe 布特哈志略 [Notes on Butha]. Reprint edited by Meng Jingshuang孟鏡雙, Taipei: Chengwen chubanshe.

Mullaney, Thomas. 2011. Coming to Terms with the Nation. Ethnic Classification in Modern China. Berkeley: University of California Press.

NZBZ (Neimenggu zizhiqu bianjizu 內蒙古自治區編輯組). 1986. Ewenke zu shehui lishi diaocha 鄂溫 克族社會歷史調查 [Social History Research Investigations of Evenki]. Huhehaote: Neimenggu renmin chubanshe.

NZEY (Neimenggu zizhiqu Ewenke yanjiuhui 內蒙古自治區鄂溫克研究會) and HEY (Heilongjiang sheng Ewenke yanjiuhui 黑龍江省鄂溫克研究會), eds. 2007. Ewenke diming kao 鄂溫克地名考 [Research on Evenki Toponyms]. Beijing: Minzu chubanshe.

QRDDMWB (Quanguo renmin daibiao dahui minzu weiyuanhui bangongshi 全國人民代表大會民族 委員會辦公室), ed. 1957. Neimenggu zizhiqu hulunbei'er meng arong qi chabaqi xiang suolun zu qingkuang: suolun zu diaocha cailiao zhiyi 內蒙古自治區呼倫貝爾盟阿榮旗查巴奇鄉索倫族情 況: 索倫族調查材料之一 [Situation of the Solon of the Chabaqi Village, in Arong Banner of Hulunbuir League in Inner Mongolia Autonomous Region. One of the Documents Related to the Solon]. Beijing: Quanguo renmin daibiao dahui minzu weiyuanhui bangongshi.

QZWXW (Quanguo zhengxie wenshi he xuexi weiyuanhui 全國政協文史和學習委員會), ed. 2008. Ewenke zu bainian shilu 鄂溫克族百年實錄 [Century Record of Evenki Minority]. Beijing: Zhongguo wenshi chubanshe.

Shirokogoroff, S. M. [1929] 1979. Social Organization of the Northern Tungus: With Introductory Chapters Concerning Geographical Distribution and History of These Groups. Reprint 1979, New York: Garland Publishing. 
Tang Wenfang and He Gaochao. 2010. Separate but Loyal: Ethnicity and Nationalism in China. (Policy Studies 56). Honolulu, HI: East-West Center.

Xi Qing 西清. (1810) 1936. Heilongjiang waiji 黑龍江外記 [Unofficial Records of Heilongjiang]. Reprint, Beijing: Shangwu yinshuguan.

Zatsepine, Victor. 2007. "Amur: As River, as Border." In The Chinese State at the Borders, edited by Diana Lary, 151-161. Vancouver: UBC Press.

Zhao Jinguang 趙金銧. 2014. “Qingdai Suolun mingjiang Hailancha jiazu renwu kao 清代索倫名將海 蘭察家族人物考." [An Investigation of the Clan Members of the Famous Qing Solon General Hailancha]. Hulunbei'er xueyuan xuebao 22 (6): 37-40. 